\title{
Laparoscopic Cholecystectomy in 2,750 Cases in a Teaching Hospital in Kuwait
}

\author{
Wael Fathi Hasaniah Ibrahim Ghada Al-Hadeedi Sabah Al-Hader Sulaiman \\ Mohamed J amal J amal Sultan Al-Shehab Derar
}

Department of Surgery, Al-Amiri Hospital, Kuwait

\section{Key Words}

Laparoscopic cholecystectomy · Acute cholecystitis . Endoscopic retrograde cholangiopancreatography . Common bile duct injury - Operative cholangiogram

\begin{abstract}
Objective: To retrospectively analyse all laparoscopic cholecystectomies performed between April 1992 and May 1999. Methods: Medical records of 2,750 patients, clinically diagnosed with gall bladder disease, were reviewed. We analysed the operative time, length of postoperative hospital stay, conversion rate, intra- and postoperative complications as well as management outcome. Results: The mean operative time was $59.2 \mathrm{~min}$, and the mean postoperative hospital stay was 1.46 days. However, the majority of our patients (66.8\%) were discharged after 1 day. The conversion rate was 3.8\%, which was mainly due to acute gall bladder pathology. The postoperative complication rate was $4.6 \%$; all cases were managed successfully with no mortality or delayed morbidity. Conclusion: Our findings indicate that laparoscopic cholecystectomy appears to be a safe and effec-
\end{abstract}

tive procedure with low morbidity and no mortality. Therefore, it should be considered as the procedure of choice for patients with gall bladder disease.

Copyright $@ 2002$ S. Karger AG, Basel

\section{Introduction}

Laparoscopic cholecystectomy has become the procedure of choice for management of gall bladder disease and has likewise gained worldwide acceptance $[1,2]$. It was introduced in Kuwait in 1992, where the first centre to perform the procedure was Al-Amiri Hospital. However, concerns remain about its safety, owing to isolated reports of fatal complications [3, 4] and controversies concerning the management of common bile duct stones in the era of laparoscopic cholecystectomy [5, 6]. Consequently, we decided to analyse all laparoscopic cholecystectomies performed between April 1992 and Mai 1999 to determine operative time, conversion rate and its causes, length of postoperative hospital stay, and complications related to morbidity and mortality.

\begin{tabular}{ll}
\hline KARGER & ( ) 2002 S. Karger AG, Basel \\
$1011-7571 / 02 / 0114-0176 \$ 18.50 / 0$ \\
$\begin{array}{l}\text { Fax +4161306 12 34 } \\
\text { E-Mail karger@karger.ch } \\
\text { www.karger.com }\end{array}$ & $\begin{array}{l}\text { Accessible online at: } \\
\text { www.karger.com } / \mathrm{mpp}\end{array}$
\end{tabular}

Dr. Wael Fathi Hasaniah

PO Box 1002

32011 Hawalli (Kuwait)

Tel. +965 2464724, Fax +9652447584

E-Mailwaelfh@yahoo.com 


\section{Subjects and Methods}

The medical records of 2,750 patients clinically diagnosed with gall bladder diseases at Al-Amiri Hospital, Kuwait between April 1992 and May 1999 were retrieved. There were 715 males and 2,035 females, ranging in age from 6 to 96 years (mean 40.2 years). Gall bladder disease was diagnosed on the basis of clinical history and ultrasound examination. The major indications for surgery included chronic calcular cholecystitis in 2,216 cases, acute calcular cholecystitis in 292 cases, biliary pancreatitis in 86 cases, and obstructive jaundice in 100 cases. Other indications are shown in table 1.

Laparoscopic cholecystectomy was performed electively in 2,343 cases, and on an urgent basis in 352 cases (during the same hospitalization and on the first operation list, while in 55 cases, the operation was done on an emergency basis (within $24 \mathrm{~h}$ from hospital admission); 330 patients had previous abdominal surgery, mainly appendectomies and caesarean sections.

Prophylactic antibiotics (cephalosporins) were given to all patients immediately before the induction of anaesthesia, and a nasogastric tube was inserted routinely in all patients during the perioperative period. Laparoscopic cholecystectomy was performed according to the standard technique as described elsewhere [7,8], basically using four ports with insufflation of $\mathrm{CO}_{2}$ through the umbilicus to establish the pneumoperitoneum. Exposure of the Calot's triangle as well as dissection of the gall bladder was done using a curved hook with monopolar electrocautery coagulation current, as previously described $[9,10]$.

As intraoperative cholangiogram was not done routinely in our practice, it was done only in 32 cases either when raised liver enzymes were present and endoscopic retrograde cholangiopancreatography (ERCP) could not be done or for training purposes. ERCP was performed pre-operatively in 299 cases when common bile duct stones were suspected because of elevated liver enzymes or a dilated common bile duct was detected by ultrasound. Common bile duct stones in 155 cases were removed by endoscopic sphincterotomy.

\section{Results}

The operative time ranged from 18 to 310 min (mean $59.2 \mathrm{~min}$ ). The prolonged time was due to difficult procedure, especially in cases of acute cholecystitis. The postoperative hospital stay ranged from 1 to 40 days (mean 1.46 days). Our policy aimed to discharge patients on the 1st postoperative day. This was achieved in 1,838 patients (66.8\%), and 495 patients (18\%) were discharged after 2 days. The remaining 417 were discharged on the 3rd day or later following surgery, except for only 1 patient who had bile leakage that required recurrent percutaneous aspirations as well as ERCP; he was hospitalized for 40 days and eventually fully recovered. The reasons for prolonged hospital stay are shown in table 2.

We achieved an overall success rate of $96.2 \%$, with a conversion rate of $3.8 \%$. The reasons for conversion are shown in table 3: the leading cause was severe gall bladder pathology, including acute cholecystitis and empyema
Table 1. Indications for laparoscopic cholecystectomy

\begin{tabular}{lr}
\hline & Cases \\
\hline Chronic calcular cholecystitis & 2,216 \\
Acute calcular cholecystitis & 292 \\
Biliary pancreatitis & 86 \\
Obstructive jaundice & 100 \\
Gall bladder polyps & 35 \\
Acalcular cholecystitis & 7 \\
Mucocele of the gall bladder & 7 \\
Cholangitis & 1 \\
Adenomyosis & 2 \\
Porcelain gall bladder & 2 \\
Gall bladder dyskinesia & 2 \\
\hline
\end{tabular}

Table 2. Reasons for prolonged hospital stay (more than 1 day)

\begin{tabular}{lrr}
\hline Reason & \multicolumn{2}{l}{ Cases } \\
\cline { 2 - 3 } & $\mathrm{n}$ & $\%$ \\
\hline Conversion & 106 & 3.8 \\
Gall bladder pathology & 177 & 6.4 \\
Patient's request & 157 & 5.7 \\
Major complications & 39 & 1.4 \\
$\begin{array}{l}\text { Others (minor complications, medical illness, } \\
\quad \text { concomitant procedure, anaesthesia }\end{array}$ & & \\
$\quad$ complications, etc.) & 433 & 15.7 \\
\hline
\end{tabular}

Table 3. Reasons for conversion

\begin{tabular}{lc}
\hline Reason for conversion & Cases \\
\hline Gall bladder pathology & 57 \\
Adverse anatomy & 30 \\
Bile leak and stone spillage & 21 \\
Abdominal adhesions & 20 \\
Cystic artery bleeding & 16 \\
Duodenal and small intestine injury & 3 \\
Common bile duct injury & 3 \\
\hline
\end{tabular}

where the anatomy was obscure and dissection difficult. Conversion, mandatory in 22 cases, was due to uncontrolled bleeding in 16 cases, duodenal and small intestinal injury in 3 , and common bile duct injury in 3 . The duodenal injury was due to a small laceration caused by the diathermy hook. It was repaired immediately and the patient 
Table 4. Postoperative complications

\begin{tabular}{lc}
\hline Type of complication & Cases \\
\hline Wound complications & 63 \\
Retained stones & 16 \\
Abdominal collection & 13 \\
Bleeding & 13 \\
Bile leak & 11 \\
Pancreatitis & 6 \\
Intestinal obstruction & 5 \\
Mortality & 0 \\
\hline
\end{tabular}

fully recovered. The small intestinal injury was due to port insertion caused by adhesions from previous surgery. The common bile duct injuries, recognized intraoperatively, were minor lacerations that were repaired immediately after converting to open cholecystectomy. All patients did well; they were discharged in good condition and on follow-up had no delayed morbidity.

Our postoperative complications, totalling 127 cases, are shown in table 4 . Among the 11 cases of bile leak, the source was cystic duct in 7, liver bed in 1, no identifiable source in 1, failed ERCP in 1, and refusal of ERCP in 1. Re-operation was necessary in 7 cases.

The 13 cases of postoperative bleeding all needed laparotomy. The source of the bleeding was from the cystic artery in 3 cases, gall bladder bed in 5, umbilical port in 4, and no identifiable source in 1. Postoperative wound complications were found in 63 cases in the form of minor infections, haematomas, and keloid formation. Incisional hernia at the umbilical port was found in 12 cases.

Postoperative ERCP was done in 36 cases, mainly to deal with complications such as bile leakage, pancreatitis and retained stones; all were successfully managed by ERCP and papillotomy. We also had 5 cases of intestinal obstruction, 3 of which were due to prolonged ileus. The 2 remaining cases were due to the small bowel knuckled into the umbilical port; 1 was managed by laparotomy and the other by laparoscopy.

\section{Discussion}

Laparoscopic cholecystectomy has the major advantage of reducing tissue trauma since the resulting wounds are small, significantly reducing length of hospital stay as well as postoperative analgesia and complications. In our practice, $66 \%$ of the patients were discharged after 1 day and another $18 \%$ after 2 days consistent with a previous report [11]. Pain control was achieved by NSAIDS in the majority of cases and few required stronger analgesia.

However, since laparoscopic cholecystectomy was introduced, questions about its safety remain concerning serious complications and increased common bile duct injuries $[12,13]$. In our practice, the major complication rate was $1.7 \%$, attributable to 3 cases of minor common bile duct injury. This low rate, consistent with that in the literature [13-15], reflects our policy of meticulously dissecting the junction between the cystic duct and Hartman's pouch of the gall bladder to ensure that the anatomy of the Calot's triangle is clearly visible; if the anatomy remains obscure, we immediately convert [16].

We did not do routine intraoperative cholangiogram as this involves additional expense and increased operating time, as previously reported [17]. Instead, we relied basically on ERCP to diagnose and manage suspected common bile duct stones both pre- and postoperatively as well as to manage postoperative complications such as bile leak, retained stones and pancreatitis, as done by others [18-20].

\section{Conclusion}

In our experience, laparoscopic cholecystectomy appears to be a safe and effective procedure, with a low rate of morbidity and no mortality. Therefore it should be the procedure of choice in managing gall bladder disease. 


\section{References}

1 Schirmer BD, Edge SB, Dix J, Hyser MJ, Hanks JB, Jones RS: Laparoscopic cholecystectomy: Treatment of choice for symptomatic cholelithiasis. Ann Surg 1991;213:665-676.

2 Anderson RE, Hunter JG: Laparoscopic cholecystectomy is less expensive than open cholecystectomy. Surg Laparosc Endosc 1991;1:8284.

3 Poulin EC, Mamazza J, Litwin DE, Nagy AG, Girotti MJ: Laparoscopic cholecystectomy: Strategy and concerns. Can J Surg 1992;35: 285-289.

4 Peters JH, Ellison EC, Innes JT, Liss JL, Nichols KE, Lomano JM, Roby SR, Front ME, Carey LC: Safety and efficacy of laparoscopic cholecystectomy: A prospective analysis of 100 initial patients. Ann Surg 1991;213:3-12.

5 Phillips EH, Liberman M, Carroll BJ, Fallas MJ, Rosenthal RJ, Hiatt JR: Bile duct stones in the laparoscopic era: Is preoperative sphincterotomy necessary? Arch Surg 1995;130:880885

6 Phillips EH: Controversies in the management of common duct calculi. Surg Clin North Am 1994;74:931-948.

7 Phillips E, Daykhovsky L, Carrol B, Gershman A, Grundfest WS: Laparoscopic cholecystectomy: Instrumentation and technique. J Laparoendosc Surg 1990;1:3-15.
8 Cuschieri A, Berci G, McSherry CK: Laparoscopic cholecystectomy. Am J Surg 1990;159: 273.

9 Hunter JG: Laser or electrocautery for laparoscopic cholecystectomy? Am J Surg 1991;161: 345-349.

10 Voyles CR, Meena AL, Petro AB, Haick AJ, Koury AM: Electrocautery is superior to laser for laparoscopic cholecystectomy. Am J Surg 1990; $160: 457$.

11 Grace PA, Quereshi A, Coleman J, Keane R, McEntee G, Broe P, Osborne H, BouchierHayes D: Reduced postoperative hospitalization after laparoscopic cholecystectomy. Br J Surg 1991;78:160-162.

12 Richardson AJ, Brancatisano R, Avramovic J, Roney W, Little JM: Injuries to the bile duct resulting from laparoscopic cholecystectomy. Aust N Z J Surg 1993;63:684-689.

13 Adams DB, Borowicz MR, Wootton FT 3rd, Cunningham JT: Bile duct complications after laparoscopic cholecystectomy. Surg Endosc 1993;7:79-83.

14 Ferguson CM, Rattner DW, Warshaw AL: Bile duct injury in laparoscopic cholecystectomy. Surg Laparosc Endosc 1992;2:1-7.
15 Schol FP, Go PM, Gouma DJ: Outcome of 49 repairs of bile duct injuries after laparoscopic cholecystectomy. World J Surg 1995;19:753756.

16 Lo CM, Fan ST, Liu CL, Lai EC, Wong J: Early decision for conversion of laparoscopic to open cholecystectomy for treatment of acute cholecystitis. Am J Surg 1997;173:513-517.

17 Barkun JS, Fried GM, Barkun AN, Sigman HH, Hinchey EJ, Garzon J, Wexler MJ, Meakins JI: Cholecystectomy without operative cholangiography: Implications for common bile duct injury and retained common bile duct stones. Ann Surg 1993;218:371-377.

18 Brooks DC, Becker JM, Connors PJ, CarrLocke DL: Management of bile leaks following laparoscopic cholecystectomy. Surg Endosc 1993; 7:292-295.

19 Mehta SN, Pavone E, Barkun JS, Cortas GA, Barkun AN: A review of the management of postcholecystectomy bile leaks during the laparoscopic era. Am J Gastroenterol 1997;92: 1262-1267.

20 Lee VS, Chari RS, Cucchiaro G, Meyers WC: Complications of laparoscopic cholecystectomy. Am J Surg 1993;165:527-532. 